\title{
Theory and Practice of Electronic Records' Archival Storage
}

\author{
MIKHAIL V. LARIN, DR., PROF.
}

Head of the Department of electronic records management systems, Historical and Archival Institute of the Russian State University for Humanities (RGGU), Russia, Moscow, 125993, GSP-3, Miusskaia pl., 6, Tel: +7 495 628-52-97, mobile: +7910 4210529

e-mail:mik091947@gmail.com; asdou@yandex.ru

\section{Theory and Practice of Electronic Records' Archival Storage}

\section{ABSTRACT}

The problem of electronic records' archival storage in modern world is very actual. Scientists and specialists from many countries are actively working on their solution. Archivists of the Russian Federation pay considerable attention to this field of archival activity, developing methods of working with archival electronic (digital) documentation. The report includes an analysis of main developments and tasks needed to be solved in the sphere of electronic records in order to create a program for efficient work with electronic records in archives.

Key words: archives, electronic records, security, preservation, archival record, long-term storage, storage rules, information technologies

\section{Teoria e pratica della conservazione archivistica dei documenti digitali}

\section{SINTESI}

Il problema dell'archiviazione dei documenti elettronici nel mondo moderno è molto attuale. Scienziati e specialisti di molti Paesi stanno lavorando attivamente alla soluzione. Gli archivisti della Federazione Russa prestano notevole attenzione a questo settore di attività archivistica, sviluppando metodi di lavoro con la documentazione elettronica (digitale). La relazione comprende un'analisi dei principali sviluppi e dei compiti necessari nel campo delle registrazioni elettroniche al fine di creare un programma di lavoro efficiente con gli archivi elettronici.

Parole chiave: archivi, documenti elettronici, sicurezza, conservazione, documento archivistico, conservazione a lungo termine, norme per la conservazione, tecnologie informatiche

\section{Teorija in praksa hrambe elektronskih zapisov}

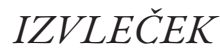

Problem hrambe elektronskih zapisov v sodobnem svetu je zelo aktualen. Znanstveniki in strokovnjaki iz številnih držav aktivno iščejo rešitve. Arhivisti Ruske federacije posvečajo veliko pozornost temu področju arhivske dejavnosti, pri čemer razvijajo metode dela z elektronskim (digitalnim) arhivskim gradivom. Prispevek prinaša analizo razvoja in nalog, ki jih je potrebno rešiti na področju elektronskega arhivskega gradiva, da bi ustvarili program za učinkovito delo z elektronskim arhivskim gradivom $\mathrm{v}$ arhivih.

Ključne besede: arhivi, elektronsko arhivsko gradivo, varnost, ohranjanje, arhivsko gradivo, dolgoročna hramba, pravila hrambe, informacijske tehnologije

\section{Теория и практика архивного хранения эмектронных документов}

\section{АННОТАЦИЯ}

Проблема хранения архивных электронных документов в современных условиях является весьма актуальной. Ученые и специалисты многих стран активно работают наА их решением. Архивисты Российской Федерации уделяют значительное внимание этой сфере архивного дела, разрабатывая методики работы архивов с электронной (цифровой) документацией. В реферате Аан анализ основных разработок и 
раскрыты основные задачи, которые необходимо решить в сфере электронных документов, чтобы сформировать программу действий Аля эффективной работы с электронными документами в архивах.

Ключевые слова: архив, электронный документ, обеспечение сохранности, архивный документ, Аолгосрочное хранение, правика хранения, информационные технологии.

\section{Introduction}

The problem of electronic records' archival storage in modern world is very actual. Scientists and specialists from many countries are actively working on their solution. Archivists from the Russian Federation also devote considerable attention to this field of archival activity. Great progress was made in theoretical research and development of practical solutions, concerning the work of archives with electronic (digital) documentation. However, the accumulated experience is not enough for complete solution of this problem. Therefore, in this report I will analyze the current situation and main tasks, needed to be solved in the field of electronic records in order to make conclusions about the measures to be taken to full implementation of electronic records in the work of archives.

\section{Terminology}

Scientific analysis shows that there are serious terminological differences, concerning electronic records. Unfortunately, among scientists and specialists of Russia there is no common understanding of electronic record, which is reflected in a number of national regulations and standards.

First of all, there is no legislative definition of a concept "record". For example, the current law on information has the term "recorded information", but the concept of record is not formulated (see $\Phi$ edeральныцй закон от 27.07.2006 N 149-Ф3). No specialist will risk to identify the concepts of "recorded information" and "record" today. At the same time, the law contains the concept of electronic record, which was introduced into the law not so long ago. If we carefully analyze this definition, it becomes obvious that legislators understand electronic record as recorded information, presented in the electronic form: in a form, suitable for human perception, using electronic computers, as well as for transmission over information telecommunications networks or for processing within information systems.

This definition emphasizes aspects of the record as a means of communication, as an object for transmission of recorded information on different types of information telecommunications networks or systems. Unfortunately, according to the theory of records management and requirements for the record of the standard ISO 15489 (ГОСТ Р ИСО 15489-1-2007), we can't rely on this definition of electronic record. The definition does not include the requirements for its content (authenticity, integrity), nor the legal status of the record. This is a disadvantage of this definition.

The same situation is with the definition of electronic record in a number of national standards (see ГOCT 2.051-2013). As a rule, we can see that they deal with the technical side of electronic record: an electronic record is a record in a digital form, for the use of which it is necessary to have computer facilities or other specialized devices for reproducing text, sound and images.

It is even more interesting to define the "record in electronic form" in the rules for exchange of recorded information, developed by the Ministry of Communications and approved by the Decree of the Government of the Russian Federation in December 2014 (Постановление Правительства РФ от 25 декабря 2014 z. N 1494). It is stated that the record in electronic form is a structured set of data, processed by using information technologies, which is an established set of metadata, including metadata, containing registration data of the record and a strengthened qualified electronic signature there.

Neither records managers nor archivists can agree with understanding of the record as a structured set of data. The most important feature in the record for us is its content and, of course, confirmation of its authenticity on the base of appropriate metadata.

This series of examples could be continued. There are more than two dozen definitions of electronic record, similar to those, listed above, in various regulatory acts. So, we can conclude that there is no 
unambiguous definition of electronic record in the legislation. Such situation leads to certain difficulties in the appraisal of electronic records.

Given this situation, it is proposed to understand electronic record as an electronic record, the information of which is presented in electronic (digital) form. A record, in turn, is defined as recorded information, which can be identified by the appropriate metadata. Of course, we can't say that this definition is ideal, but today it is the most successful.

In any case, specialists, especially practitioners, should come to a common understanding of electronic record.

\section{Categorization of electronic records}

As a result of scientific analysis, we propose to classify four groups of records as "electronic records".

First of all, these are electronic records, the entire life cycle of which takes place electronically.

The second group of electronic records is digital copies of paper and other analog records.

The third group, you can also name databases, which in some cases can be specific objects of archival storage (registers, lists, cadasters).

The fourth group are web records that appear in the Internet today, including social networks, websites and websites themselves. They can also be regarded as specific electronic records.

Taking into account the above systematization, it is necessary to move towards the introduction of electronic records into our life, to our practice. If we talk about records management, we propose an approach, based on professional analysis of the composition of paper types in organizations and gradual replacement of paper records with electronic ones. Naturally, the replacement should be kept taking into account archival value of records, fulfilling the principle of distinguishing three types of records, according to the criterion of records' value.

According to the current archival rules, as far as retention periods are concerned, records are divided into records of permanent, temporary (over 10 years) and temporary (up to 10 years inclusive) retention periods. If the paper records of the third category (up to 10 years inclusive) can be surely replaced by electronic records, then the records from sets of temporary (over 10 years) and permanent storage one should carefully insert electronic records, replacing them with paper records, where possible, without any damage to the security of records in the future.

An unambiguous position is not developed in archival science, regarding archival storage of modern information resources: databases, electronic messages, registers, web-sites and web-records. Therefore, here we can see a large space for scientific research. Only after comprehensive scientific analysis and theoretical justification we can make conclusions about effectiveness of archival storage of such information.

\section{Electronic signature}

Archivists have a lot of questions about electronic signature as an indispensable metadata of electronic record. The electronic signature of the record in the process of transferring it to archival storage is an acute problem of scientific discussions. However, archivists are in need of practical solutions today. After comprehensive study of this issue, we came to the conclusion that the electronic signature of the record should complete its life cycle in the records management, and the record should be transferred to archives without current electronic signature, but with preserved metadata about it.

\section{Storage formats}

Another important factor, affecting the storage of electronic records is storage formats. Unfortunately, the issue of storage formats has not been fully solved yet. There are different points of view on this problem. This task is solved for text records. But there is still no universal solution in our practice for the whole range of records, including scientific and technical, audiovisual, video - phono - photo records. 


\section{The Rules for working with archival electronic records}

"The Rules for storage, acquisition, control and use of the Russian Federation Archival Fund' records and other archival records in public authorities, local government and organizations" (Приказ Министерства культурь РФ от 31 марта 2015 г. № 526), recently developed, is an example of practical solutions of the issues, related to electronic records. The Rules have the status of a normative act and should be used in each archives of the Russian Federation.

For the first time, the Rules reflect modern understanding of electronic records and requirements for their storage, acquisition, control and use. According to the Rules, all relevant conditions for storing and working with electronic records should be provided in archives. The established storage format of textual electronic records is $\mathrm{PDF} / \mathrm{A}$.

The second major innovation of the Rules is the container method of transferring electronic records for archival storage in accordance with the international standard (see ISO/IEC 21320-1:2015). For the first time, a norm has been introduced into the Rules, which has not been fully tested in practice yet. However, we are introducing "container of electronic record", since this method is recommended by the Ministry of Communications for the transmission of electronic records on telecommunications networks in the process of interaction between authorities. Such an order is approved by a decree of the Government of the Russian Federation, which means that it is a legal norm.

According to the Rules, the container includes the electronic record itself in the original format, its copy in PDF/A format and metadata files, including electronic signatures that accompanied this document during its life cycle. Thus, a container is not a physical, but a virtual object.

So, the Rules include two clear positions: 1) electronic textual records of permanent storage must be transferred to archives and stored in PDF/A format; 2) for electronic records, the technology of container formation is provided while transferring to archives.

\section{Problems of working with electronic records}

First of all, we must repeat a well-known truth, that electronic records are dependent on hardware and software, and it is very difficult to keep them in an unchanged (authentic) form for a long period of time. Electronic records are not physical, but logical structure. The features of their storage on different computer devices depend on the technologies, in which they were created. Today, there is no single universal technology for storing various categories and types of electronic records.

The fact, complicating the situation, is that electronic records are easy to create, multiply, translate from format to format, spread over telecommunications networks or using removable media. Such concepts as a duplicate of an electronic record, a copy of electronic record have appeared. In this situation it is necessary to achieve terminological purity from the point of view of records management and archival activity. A false idea that there can be many originals of record is also connected with the appearance of electronic records. And, certainly, from a professional point of view, we can talk about the archival record as an immutable entity. For records managers and archivists, the record is valuable precisely, because its content does not change over time and in space, it works in the form, in which it was created, formed, signed and received legal force. If we change its contents or even its individual details (metadata), then another record appears.

Recently there was an idea, that archives should store not only records, but also data from an external information environment. But, there is a question about turning archives into information (data) center, if it stores data and information in the form of databases. It seems that there should be a clear boundary between archives and information structures. We believe, that archives is an institution for storing archival records, but not separate data. This position corresponds to the norms of the Russian archival law.

There are already proposals to keep not original records, but only meaningful information from them. It seems to me, that as long as we have the opportunity to save records, we must preserve records, not the content of these records. The theory of archival science teaches that for the record as a historical source it is important not only the content, but also its metadata author's notes, design features, etc. All 
this is valuable for the record and as evidence, regardless if it is electronic record or record, prepared on a traditional paper medium.

\section{The infrastructure of electronic records' storage}

The experience shows, that traditional archives are not suitable for effective storage of digital records. So, different ideas were proposed to solve this problem. For example, in order to provide continued preservation of electronic records, the European archivists proposed as one of the methods to store records at the place of their creation on those technical means and in the information systems, in which they were created. For example, scientific and technical documentation, created by scientific or production enterprise is proposed to be stored at the place of creation, and the archives only consider it as potential archival records. Certainly, such options are possible. But when records are out of archives, it is difficult to provide full control over their safety and to organize their full use.

There are also ideas to store archival electronic records in the "clouds". This is the concept, that our Ministry of Communications offers now. There is a plan to create state data repository (big data) and to place electronic records with an archives' status in it. With this option, the Federal Archival Agency should become an agent of this huge data repository and store electronic records in it. Other organizations at the federal level can also store their electronic records in this cloud. Such a plan is viable, but only if Rosarchiv retains the function of comprehensive control over the activities of this structure. In this case, one can take the experience of the USA or Germany as a model.

For example, in the USA the method of archival records' storage, using cloud technologies, is applied in accordance with the Directive of the National Archives and Records Administration (NARA). If a ministry chooses a cloud to store records, then the leadership of this ministry takes all the risks and responsibility for safety of these archival records. NARA offers departments a list of trusted cloud services to be used (see U.S. National Archives and Records Administration). In Germany they chose some different way. It was decided to organize a so-called interim archives for electronic records' storage, until their appraisal, within the structure of the Bundesarchiv. After this procedure, electronic records are selected for storage in the national archives.

This is a complex question - what way we will choose, there is no unambiguous answer to it. If the concept of the Ministry of Communications on the creation of a center for electronic records' storage is realized, then there will be those records, related to the acquisition sphere of state archives. And, certainly, there is a danger for the records to be outside the archives. An electronic record is a very fragile object, which is subject to various hazards in the form of virus attacks or physical influence. Thus, archivists and specialists in informatics are looking for various technologies for best organization of their storage in archives.

\section{Organization of electronic records' storage}

In practice, there are several basic methods for organizing of electronic records' storage. All of them have been experimentally tested. One of the methods, often called as museum method, assumes that archives will store not only electronic records themselves, but also software, as well as technical means, that this software can reproduce.

This approach was applied at the turn of the century by the National Archives of Great Britain (see Digital Strategy). However, in the modern world the museum approach has not been supported by archivists because of high costs for its implementation. It is impossible to recommend as a standard solution what can be created in one museum. As a rule the Russian archives do not have any extra space, or sufficient funding, especially in our practice. This method is not realistic. Therefore, it is necessary to think, what methods one should apply in order to preserve electronic records. These problems are solved in different ways in archival world.

There are publications on migration and emulation technologies on this topic. Migration, as the most often used strategy today, means that archives must constantly monitor how software changes in the external environment of archives or in the archival information system, and constantly convert files from obsolete formats to new ones. We must honestly admit, that there will be loss of some information there. And archivists need to think about the extent, to which they agree to lose some information, while rewri- 
ting electronic records in the migration process. Is this acceptable for us or not? Only after making appropriate research and experiments we should make decisions on application of migration method.

The emulation strategy implies preservation of software environment over a long period of time. It is supposed that electronic records' formats will be supported by emulation, i.e. continuity of subsequent software tools in relation to the previous ones. However, the historical experience points to the shortcomings of this method. For example, records, created in the Russian text editor "lexicon" $\left(80-90^{\text {th }}\right.$ years of the last century), with the help of modern editors can't be read. It is impossible to use some media of those times. Therefore, we should make some scientific study on this problem for getting reliable methods of electronic records' storage.

\section{References}

Cvelfar, B. (2016). On Our Way to Slovenian Digital Archives. - In: Alma Mater Europaea. $5^{\text {th }}$ International Scientific Conference: All about People: Interdisciplinarity, Transnationality and Building Bridges. Book of abstracts. - Maribor. - 2017. - March 10-11. - pp. 255-256.

Digital Strategy, National Archives of Great Britain. Available at http://www.nationalarchives.gov.uk/documents/the-national-archives-digital-strategy-2017-19.pdf.

ISO/IEC 21320-1:2015 "Information technology - File-container for the record. Part 1: The main part (Information technology - Record Container File - Part 1: Core)".

U.S. National Archives and Records Administration Fiscal Year 2014 - 2019. Available at https://www.archives. gov/files/about/plans-reports/strategic-plan/2013/nara-strategic-plan-2014-2019.pdf.

ГОСТ 2.051-2013 «Единая система конструкторской документации. Электронные документы. Общие положения». М.: Стандартинформ, 2014. С.2.; ГОСТ Р «СИБИД. Электронные документы. Основные виды, выходные сведения, технологические характеристики. М.: Стандартинформ, 2015, $11 \mathrm{c}$.

ГОСТ Р ИСО 15489-1-2007. «СИБИА. Управление документами. Общие требования» М.: Стандартинформ, 2007, 34c.

Постановмение Правительства РФ от 25 декабря 2014 г. N 1494 «Об утверждении правил обмена документами в электронном виде при организации информационного взаимодействия». Available at http://government.ru/media/files/nMmMtsiIcAE.pdf.

Приказ Министерства культуры РФ от 31 марта 2015 г. № 526 (зарегистрирован Минюстом России 7 сентября 2015 г.) «Об утверждении Правил организации хранения, компмектования, учета и использования документов архивного фонда Российской Федерации и других архивных документов в органах государственной вцасти, органах местного самоуправмения и организациях». Available at http://www.garant.ru/ products/ipo/prime/doc/71083090/

Федеральный закон от 27.07.2006 N 149-Ф3 (ред. от 13.07.2015) «Об информации, информационных технологиях и о защите информации» // СЗРФ, 31.07.2006, N 31 (1 ч.), ст. 3448.

\section{SUMMARY}

The report analyzes main developments and tasks, needed to be solved in the theory and practice of archival storage of electronic records in order to form an action plan for scientists and specialists in creating practical methodology for efficient work with electronic records in the Russian archives. Despite the fact that, in the whole, the report is based on the Russian practice, a number of questions, stated in the report, are of importance for international practice. First of all, the questions on terminology are to be solved. An unambiguous understanding of electronic record' essence will bring closer the answers to questions about authenticity, integrity, legal significance, appraisal of electronic records, which have not been clarified yet. It is proposed to classify four groups of records as "electronic records". The main ones are those records, which entire life cycle is in electronic form and digital copies of paper and other analog records. The report deals with the use of electronic (digital) signature while working with electronic records, storage formats, a new way of digital records' storage by the "container" method. The report examines some scientific problems of digital records' storage, related to the features of technologies for managing electronic records, requirements for infrastructure of storage and methodological bases for supporting the life cycle of electronic records during their archival storage. At present, the Russian archivists, quoting and agreeing with "Digital Strategy of the National Archives of Great Britain", take a lot from the approaches, used in working with physical records. We are also electronic archives of the first generation, imitating archival practice, developed 
Mikhail V. LARIN: Theory and Practice of Electronic Records' Archival Storage, 117-123

for paper records, in electronic form. In our opinion, only qualified development of methods on working with electronic archival records of the first stage, getting confident knowledge and experience, based on scientific and methodological solutions, will allow the Russian archivists to face the digital future with confidence.

Typology: 1.02 Review Article

Submitting date: 07.04 .2017

Acceptance date: 05.05 .2017 